\title{
LOOKS, GESTURES, AND WORDS: Skepticism and the Ethical in Cavell and Levinas
}

BERNARDO PORTILHO ANDRADE

\author{
We know nothing of the soul \\ Other than of our own; \\ Those of others are looks, \\ Are gestures, are words, \\ And what we assume of resemblance \\ At the bottom.
}

- Fernando Pessoa ${ }^{1}$

sense of separation from others often comes to the overly conscious student who
has just ended a conversation with his much-esteemed professor: "What did he
think of what I said?" From there arises an obsessive wish for a third-party witness, as
if in the form of a minuscule fly or a hidden camera, allowing him to revisit later the
conversation with his interlocutor: "If only I could remember exactly what happened,
as if replaying a clip, I would be able to distinguish my subjective projections from
the objective interaction!" However, even that turns out to be a futile wish, as the
despairing student realizes that no objective recording could reveal the depths of his
listener's inner states. The professor's outward expressions might be wholly distinct
from his impressions, and nothing could grant the student such privileged access -
for unless each lives for a moment in the other's mind, they will stay forever separate,

1 I am quoting my own translation of Pessoa’s untitled poem. As far as I know, no English version has been published. For the original Portuguese, see:

Pessoa, Fernando. Poesias Inéditas (1930-1935). Lisboa: Ediçōes Atica, 1955. 
forever isolated.

The problem described above - namely that my knowledge cannot seize hold of the other person and possess him; that I cannot enter into his eyes and grasp the inner workings of his soul - lies at the core of what Stanley Cavell and Emmanuel Levinas would call the "scandal of skepticism." This brings up a surprising coincidence, i.e. that an American philosopher (with intellectual roots in the works of Emerson, Thoreau, Austin and Wittgenstein) and a French-Lithuanian thinker (whose inspiration comes from the Jewish tradition and the phenomenology of Husserl and Heidegger) arrive at an uncannily similar solution to a problem perceived within two separate historical dialogues. This paper attempts to locate and explain this point of agreement. In doing so, it presents the profoundly innovative view of morality that arises from both authors' reflections on skepticism.

This enquiry departs from Cavell's late collection of essays Philosophy the Day After Tomorrow. In the book's sixth chapter, entitled "What is the scandal of skepticism," Cavell admits his surprise when reading Levinas, in particular his astonishment at the eerie similarity between their solutions to other-mind skepticism. ${ }^{2}$ Encouraged by Cavell's essay, I intend 1), to elucidate his notion of the "scandal of skepticism" and 2), to provide a short comparison between Cavell and Levinas' solutions to that scandal. I will conclude that their respective analyses of skepticism both lead to the radical statement, attributed to Levinas, that "ethics is first philosophy."

\section{CAVELL AND THE "SCANDAL OF SKEPTICISM"}

Cavell borrows his title, "the scandal of skepticism," from Kant's footnote in his preface to the second edition of the Critique of Pure Reason. As Kant says:

"It always remains a scandal of philosophy and universal human reason that the existence of things outside us... should have to be assumed merely on faith, and that if it occurs to anyone to doubt it, we should be unable to answer him with a satisfactory proof."3

What Kant finds scandalous is that the philosophy of his time still has not found a proof of the existence of external things. He opposes the claim that one can be conscious only of what is in him, i.e., his representation of external things, and that he thus cannot know whether or not there is something outside him, corresponding to it. ${ }^{4}$ Kant is hence concerned with skepticism 1), as a function of knowledge (can we know anything?), and specifically 2), of knowledge of the external world.

2 Cavell, Philosophy the Day After Tomorrow, p. 150. Cavell's feeling of surprise came after reading Levinas' collection of essays entitled Difficult Freedom, which Cavell quotes at length in the sixth chapter of his book.

3 Kant, Immanuel, Preface to the Second Edition, Critique of Pure Reason, B xl. For the specific translation referenced here, see Kant, Immanuel, Paul Guyer, and Allen W. Wood, Critique of Pure Reason.

4 Berkeley presents this anti-Kantian position in his Three Dialogues, when Philonous says, "It is a great contradiction to talk of conceiving a thing which is unconceived... you cannot possibly conceive how any corporeal sensible thing should exist otherwise than in a mind." See Berkeley, Three Dialogues between Hylas and Philonous, pp. 35-36. 
Kant's quotation also reflects his response to Humean skepticism. The passage works as a critique of Hume, who abandons his philosophical project after affirming that we rely on a natural belief in the external world and in its causal laws. The Humean notion that the mind has a habit (not a reason) that leads to beliefs about the external world explains why Kant uses the word "faith" when he states that it is a scandal of philosophy "that we should have to accept the existence of things outside us [...] merely on faith." Kant thus finds it inacceptable that Hume, as well as all thinkers before him, has not philosophically solved the problem of external-world skepticism.

Cavell, however, takes the "scandal of skepticism" in a different way. Following Wittgenstein, he embeds philosophy in ordinary language - a profound methodological shift that, as I will show, finally leads to the priority of the ethical. Unlike Kant, Cavell is not concerned with skepticism as a threat to a systematic science that studies the external world. Rather, he finds that skepticism is inherent in (ordinary) language because of the attunement of the speakers. He worries about the difficulties of communication; about the seeming impossibility of knowing whether the other person means the same as I do by the words we use. Science avoids skepticism by sublimating language in fixed rules of procedure and agreement, but our everyday use of words "is anything but invulnerable to skepticism."

Cavell wonders why philosophers so often have hubristic ambitions to go beyond the ordinary. After all, Descartes' Meditations starts with an isolated philosopher fleeing from the ordinary, trapping himself in a tiny room with some candlewax and not much else. Hume similarly takes the problem of skepticism to be divorced from ordinary life. To escape his philosophical melancholy, he dines, plays a game of backgammon, and has merry conversations with friends. This attitude certainly resonates with Hume's maxim: "Be a philosopher, but be still a man." "The concerns that trouble the philosopher seem, for Hume, not to reach man in his concrete life. That is why philosophy, throughout its history, "has chronically required of itself a flight from the ordinary." "The thinker, in his search for knowledge and certainty, has far too often decided to escape everyday life as a means of finding theoretical grounding. However, to deal with skepticism solely in the abstract realm of ontology leaves unexplored the persistent danger of skepticism in our everyday use of language. For Cavell, that is the scandal.

\subsection{CAVELLIAN SKEPTICISM AND WITTGENSTEINIAN CRITERIA}

Cavell's ordinary-language skepticism rests on what Wittgenstein calls criteria. Unlike other interpreters of Wittgenstein, Cavell does not see the Philosophical Investigation

5 Kant, Preface to the Second Edition, Critique of Pure Reason, and B xl.

6 Cavell, Philosophy the Day After Tomorrow, p. 134.

7 Hume, An Enquiry Concerning Human Understanding, "Section 1: Of the Different Species of Philosophy."

8 Cavell, Philosophy the Day After Tomorrow, p. 134 
as an attempt to refute skepticism; on the contrary, he takes Wittgenstein to show that skepticism is an inevitable by-product of ordinary language. In the usual view, criteria are presumed to rebut skepticism by establishing the existence of something with certainty. ${ }^{9}$ For example, against the skeptic who doubts that he can ever know with certainty whether or not the other is in pain, ${ }^{10}$ the philosopher can point to the criteria of pain (say, contorting one's face), the presence of which necessarily entails that the other is in pain. John Austin embodies this approach in his famous example of the goldfinch. ${ }^{11}$ If one were to disagree with Austin as to whether the bird they see is a goldfinch, Austin would simply refer him to the rulebook (in this case, to a book on birdwatching), and then tell him that since the bird they see has that black stripe in his wing, and that yellow throat, it must be a goldfinch. In other words, these are the criteria that establish what it means to be a goldfinch. To disagree with Austin would entail that one does not know what a goldfinch $i$; what its criteria are.

For Cavell, on the other hand, criteria cannot settle the skeptic's worries. Far from dismissing skepticism, a correct understanding of criteria shows skepticism to be irrefutable. Criteria belong solely to the way we agree within language, and not to any context-less and independently existing rulebook. No rulebook could ever account for the flexibility and creativity with which I employ my concepts, establish commitments, and make myself responsible. Nothing underlies or "governs" my application of concepts in judgments. Surprisingly, both Cavell and Levinas share this particular and highly innovative view on language. Although I am stepping ahead, this point of agreement becomes clear when Levinas says, in his collection of essays entitled Humanism of the Other, that:

Language refers to the positions of the listener and the speaker, that is, to the contingency of their story. To seize by inventory all the contexts of language and all possible positions of interlocutors is a senseless task. Every verbal signification lies at the confluence of countless semantic rivers. ${ }^{12}$

The skeptic wishes to obtain the certainty that his application of concepts is based on something robust, solid, or fixed - a structure, a manual, an impersonal metaphysics. Some commentators on Cavell and Wittgenstein (such as Stephen Mulhall and Saul Kripke), in line with the skeptical demand for a solid foundation, often emphasize the idea of language as an agreed-upon framework of rules, which relieves the speakers of responsibility for their own words, freezing or sublimating language, emptying it of its on-going flexibility and creativity. ${ }^{13}$ To such ordinary-language philosophers,

9 Hammer, Stanley Cavell: Skepticism, Subjectivity and the Ordinary, p. 32.

10 Whether physical or emotional, I take pain to be an unpleasant private experience. The significance of the pain example, which will appear multiple times henceforth, is that most people take pain to be private to their owner in the strong sense that no one else can epistemically access the other's pain in the way that one has access to his own pain.

11 Austin gives the goldfinch example, among other places, in a 1946 essay entitled "Other Minds." See Austin, James Urmson, and Geoffrey Warnock, Philosophical Papers, pp. 76-116.

12 Levinas, Humanism of the Other, p. 11.

13 Hammer, Stanley Cavell: Skepticism, Subjectivity and the Ordinary, p. 39. 
once the criteria for pain are satisfied (say, your face is contorted) the question of the non-existence of pain can be discarded. What more, they might ask, could one possibly require? This misses the point, however, that in cases of acting or feigning, it is precisely pain-behavior, and hence the satisfaction of the criteria of pain, that is being simulated. Without the possibility of simulating the satisfaction of criteria, acting or feigning would not exist. This shows that we are never in a position to know with absolute certainty that the other feels pain. The skeptic would like criteria to prove that someone really is in pain, but criteria give us certainty about identity, not existence. ${ }^{14}$ This already points to the fragility of our everyday use of words, to how language skeptically invites us to demand certainty of the other's pain: I want to act correctly, to show concern only when you really feel pain. However, all I have are your looks, your gestures and your words, and they do not suffice as criteria for existence.

When it comes to my criteria regarding the other person, it seems that I am always acting on the basis of insufficient evidence. After all, I must respond to the other's pain, to his smile or affection, and yet my criteria can never provide me with certainty of the existence of his inner states, only of its semblance: "he is expressing pain, or expressing care... but does he feel it?" A fundamental lack of knowledge permeates all of my relationships with others, and from this abyss comes my skeptical wish to fill the darkness with certainty of the other's inner states. Ordinary-language skepticism thus comes from the realization of this inevitable epistemological separation between me and the other person: "how am I supposed to respond to him, to acknowledge his pain, if I cannot know for sure that he is suffering?" To refrain from doing good is not morally neutral; to flee from the world and avoid the other already has its moral charge. Such is the reason why this Cavellian skepticism stands as primarily ethical: the ethical trauma results from the fact that my epistemological possibilities reach up to a certain point, whereas my moral obligations extend beyond that point. For instance, I cannot know with certainty that the other is truly sad, but I must respond - here and now - to his crestfallen look.

The skeptic, troubled by Cavell's reading of Wittgenstein's criteria, thus presents a reasonable request - namely, to act out of knowledge and not out of ignorance; to have his moral actions be determined by the extent of his knowledge. Such has, after all, been the standard approach in the history of Western philosophy. Ever since Plato's Protagoras, philosophers have always taken good and virtuous actions at least to involve knowledge, not simply to be equated to knowledge. Socrates, for instance, claims that knowledge alone generates all virtues, whereas ignorance alone causes all vices. ${ }^{15}$ As Descartes similarly says in the Meditations: "From a great light in the understanding results a great propensity in the will." 16 Our will, the mover of our actions, must follow and obey the understanding. To demand otherwise, to request

14 Ibid., p. 41.

15 See Plato's Protagoras, 357b-e

16 See Descartes, Meditationes de prima philosophia, Meditation IV, \$69. I am quoting my own English translation. 
that our moral actions precede understanding, stands as a highly radical position. Far from being easily dismissible, the skeptic in fact embodies the spirit of Western philosophy when he reacts against Cavell's reading of criteria.

In order to justify Cavell's radical position - placing morality before knowledge and certainty, and thus opposing the general historical trend of Western philosophy - I will in the next few paragraphs further expose the ethical trauma of attempting to establish criteria regarding the Other on the basis of insufficient evidence. Such is the trauma of trying to have certainty of the Other's inner states as an epistemological basis for the ethical. If I show this (skeptical) approach as inherently frustrated, as an attempt for the impossible, as a recipe for disaster, then I will be able to justify Cavell's ethical response to the skeptic - namely, the primacy of ethics over certainty, or stated differently, the urgency of acknowledging the other prior to (and independently of) knowing that other. At first sight, the word 'acknowledgment' seems to contain within it the word 'knowledge,' but, interestingly enough, the only way to leave our other-mind skepticism behind is to learn how to acknowledge the other without knowing the other with certainty.

\subsection{THE ETHICAL TRAUMA OF CAVELLIAN SKEPTICISM}

If criteria grant me certainty only of the identity of something and not of its existence, as I have already shown, both external-world and other-mind skepticism become possible. For just as Cavell considers how disappointment with criteria pervades philosophy's quest for certainty about the existence of the external world, so does he take the problem of other minds to result from the wish to strip ourselves of the responsibilities and anxieties that mark our usage of criteria. I find it difficult both to know 1), whether the objects which I see as fulfilling the criteria for cars in fact exist and 2), whether the gestures which I see as fulfilling the criteria for sadness a), indeed exist and b), correspond to a real state of inner-sadness. External-world skepticism might lead to other-mind skepticism, but as we can see from the double layer of complexity in the latter case (2), it is other-mind skepticism which presents a greater problem. To be sure, Cavell thinks that both forms of skepticism cannot be easily dismissed, but he clearly devotes more time to solving the difficulties around other-mind skepticism.

If the objects around me fulfill the criteria for cars, I can very well assume the existence of those cars without any satisfactory proof, for otherwise I run the mortal risk of a traffic accident. But to assume facts about the other person - that is, to make claims about the other person and to act on those claims - can lead me to moral disaster. I can, of course, simply assume the overall existence of the other person without moral consequences (most people do), just as I did in the case of the cars. However, notice that I can also easily assume (without any moral consequence) that inside the car, I will find five seats or a big trunk, whereas I cannot assume (without moral 
consequences) that the other loves me, cares for me, or has any interest in listening to my stories. Suppose that I want to settle the question and not just assume that the car has five seats: I could open its doors and look inside. Imagine that what I see inside the car does fulfill the criteria for five seats. Being a skeptic, I can of course doubt whether I am really seeing five seats (whether they really exist), but I am nonetheless directly witnessing those five seats; that is, they are still present to me as objects to my knowledge. I can certainly doubt the powers of my own witnessing, but that is as far as I can go.

The situation concerning the other person, however, seems very different. In the latter case, I cannot directly witness the Other's inner states: I cannot feel your love for me, or your interest in my stories. I can still see your facial expressions, just as I can listen to your words of praise, but that alone is what I am directly witnessing. If I were to doubt my senses, as in the case of looking inside the car, I would analogously doubt whether I am correctly perceiving those facial expressions and those words of praise. If I were to doubt the other just as I did in the case of the car, I would doubt whether what I see indeed fulfills the criteria for, say, a smile. But my skepticism towards the other can always go further: "Is he faking? Is he merely pretending to like me? And with what intention?" This worry rests on the impossibility of my knowing whether you are enjoying my company or the food I cooked, and not on the impossibility of my knowing whether you are smiling at me, nodding your head, or holding my hand. Thus, my doubt regarding the other has two layers: a), the perception of his gestures and $b$ ), the correspondence of those gestures to his inner states. Whereby I suffer no moral consequences for suspending my worries regarding the inside of the car, I run the risk of deception, of betrayal, and of eventually ending up alone if I suspend my skeptical worries of the other's feelings.

In the previous paragraph, I advanced the notion that skeptical worries about the Other stand as a persistent possibility in ordinary language and everyday life. However, while Cavell recognizes the moral risks in completely suspending these worries (such as the risk of betrayal or deception), he particularly focuses on the danger of not suspending skeptical worries; that is, of demanding certainty of the other's inner states. The wish to possess the Other, so to speak, and to grasp him as an object of knowledge - which reminds us of our introductory paragraph - is both the wish for the impossible and the birth of a tragic fate. I intend to elucidate both of these notions in the two following subsections. The first, dealing with the impossibility of knowing the other's inner states, bases itself on Cavell's essay "Knowing and Acknowledging," from Must We Mean What We Say; the second, touching on the tragic fate of the skeptic, finds its roots in Cavell's reading of King Lear in "The Avoidance of Love," also in the same book. 


\subsubsection{SKEPTICISM AS THE WISH FOR THE IMPOSSIBLE}

My separation from others lies in the fact that, however intimate I am with some people, I am still myself and not them, and I can never truly be in their position; I can never have their feelings and thoughts, for otherwise they would be mine and not theirs. Such a separation does not describe an inability of mine, or a mistake to be corrected, but rather a general fact of the human condition. Though I can nominally have the same pain as you (e.g. accidentally hitting my thumb with a hammer as I build a treehouse), I have no means of accessing how it feels to you. I know how the pain feels to me, and I know what $I$ call it, but that name might correspond to a completely different feeling for you. In other words, it stands as a permanent possibility that the hammer could have caused a wholly distinct pain in your finger, and my inability to have your pain stops me from either confirming or denying it. With regards to my pain, "I stand sealed out from others, as well as sealed in myself." ${ }^{17}$

In discussing the skeptical problem of "having" the other's pain, ${ }^{18}$ Cavell defends Wittgenstein's interlocutor in the Philosophical Investigations, where the author says that it makes no sense to want to have the other's pain. Cavell states that the skeptic of the Investigations has discovered that unless he can share or swap feelings with the other person, he cannot know what the other is experiencing (if anything). ${ }^{19}$ Though Cavell does not think this is a perfectly unobjectionable idea, he is far from confident that he knows what is objectionable about it. To be sure, it may turn out that the question "can I have the same feeling that he does?" is badly conceived, but the point of the matter, for Cavell, lies in the fact that this has not been shown in the Investigations. ${ }^{20}$

In order to show that the skeptic's question cannot be easily dismissed, Cavell mentions the example of a couple owning two cars of the same model (both are 1952 MG-TD's). To say that the cars are the same is to say that they are not different makes, but it cannot be denied that the husband has his car and the wife hers - that there are two. ${ }^{21}$ However, when it comes to colors, if the color of this notebook fits the same description as the color of that notebook (let us say, \#250 of the Universal Color Chips) then the color of the notebooks is the same. And if a critic were to ask: "But are there not two colors, just as in the case of the cars?", Cavell would respond that unless the critic means that one of them seems closer to \#249 or to \#251, he does not know what "color" or "same" means, what a color is. ${ }^{22}$ We then conclude that with pains, as with cars - but not with colors - we can say that in one sense there are two (in terms of its "numeric identity") and in another sense there is only one (in terms of its "qualitative identity"). The whole issue of concern for the skeptic, however,

17 Cavell, Must we Mean What We Say, p. 240.

18 Wittgenstein, Philosophical Investigations, $\$ 293$.

19 Cavell, Must We Mean What We Say, p. 228.

20 Ibid.

21 Cavell, Must We Mean What We Say, p. 224.

22 Ibid. 
lies precisely in the lack (or impossibility) of numeric identity, because in the case of pain that stands as a complete impediment to knowledge. Suppose the couple can have descriptively the same pain - say, again, hitting their fingers with a hammer while building the family's tree house: Do they have the same particular pain? Can we know here and now that they do? It is as if we needed to feel a replica of their pains - first of the husband, then of the wife - in order to compare and confirm that it is the same. As Cavell states: "If this is the way things are, we do not know whether they have the same pain or not; we never can." 23

The fact that the last paragraph ends with the words "We never can [know]" already shows why Cavell calls this form of skepticism a wish for the impossible. We demand knowledge precisely of what we cannot know; we want certainty with regards to the other's inner states, which requires the abolition of numeric differences. If only we were all one single extended body with one single extended mind, without alterity, we would be able to acquire certainty of all inner states. ${ }^{24}$ One can already notice the violent nature of such a wish, the thirsting for totality or for the dissolution of the Other. Though I keep telling myself not to jump ahead, a reader of Levinas can see the incredible similarity between the two thinkers unfolding at this point. The skeptic of the Investigations - who, after all, is not unreasonable - whose claim is not easily dismissible or objectionable - has a wish for totality, a desire to encompass everything into sameness, into a sine fine self. ${ }^{25}$ But that is impossible: the other's pain is not present to me as an object of knowledge. I am inevitably confined to knowing only of the other's expressions and outward manifestations. With regards to his pain, I cannot know it, but simply accept it (to respond to his contorted face with care) or deny it (to turn away my eyes, looking out the window).

\subsubsection{SKEPTICISM BEGETS A TRAGIC FATE}

Cavell claims that tragedy (at least in its Shakespearean form) displays the structure of other-mind skepticism, a disappointment with the human finitude of criteria and the consequent denial of the "unknowable" other. In the final pages of the Claim of Reason, Cavell establishes that skepticism is intrinsically marked by its drive towards the tragic. Incapable of coming to terms with the limits of criteria, the skeptic tragically finds himself, the world, and others to be withdrawn from each other and devoid of significance. ${ }^{26}$ Such is the reason, as we shall see, why King Lear demands

23 Cavell, Must We Mean What We Say, p. 229.

24 What I have described in this sentence is an even more radical example than the one given by Cavell on p. 232 of Must We Mean What We Say. Cavell talks about two Corsican Brothers, one of whom (call him Second), suffers everything which happens to his brother (call him First). When you whip First, Second writhes with him - not in sympathy, seeing what is happening, but even miles away, not knowing what is happening to his brother. This is a way for Cavell to conceive of a situation in which both individuals have numerically the same pain. But as Cavell points out, it is not clear whether Second will express his pain by saying "I am in pain" or "He (First) is in pain." In this case, problems still arise concerning our knowledge of the other because alterity, separation and individuation are still in place. The skeptic wishes, in a way, for the abolition of individuation, which he cannot achieve.

25 The skeptical wish for the abolition of numeric differences and of otherness is the wish for a self "without end," echoing the Latin expression "Imperium sine fine," "The Empire without end," which refers to Rome.

26 Hammer, Stanley Cavell: Skepticism, Subjectivity, and the Ordinary, p. 77. 
of his daughters, so to speak, a certificate of love. Lear wants a statement of love that fixates, grounds and establishes that which can only exist in in the fragile and toohuman realm of ordinary language.

A disappointment with the limits of criteria and the consequent denial of the other mark Cavell's reading of King Lear in his essay entitled "The Avoidance of Love." As the title suggests, avoidance permeates the whole play: Gloucester refuses to recognize Edmund as his illegitimate son; Cornwall blinds Gloucester so as not to be seen by him; Lear does not reveal himself to Gloucester after the latter's blinding; and most importantly, Lear denies his love for Cordelia in the abdication scene in Act I. What Cavell finds interesting in this fateful scene from Act $I$ is that, while desperately wanting Cordelia's love, Lear sees the demand that her love makes upon him as threatening. The realization that love involves dependence strikes Lear as incompatible with his position of power and authority as king. Threatened by the fear of exposing these feelings (and thus by the fear of the dependence that these feelings entail), Lear arranges for his daughters to publicly declare their love for him, and in return he agrees to distribute his lands to each of them. Lear thus asks his daughters to make him look like a loved father, but without having to return in kind.

Cordelia, however, who loves her father, cannot accept this. Rather than giving a lofty and elevated speech of praise, offering false love in return for Lear's rewards, she chooses to remain silent. Only by refusing the dissimulated expression of love that Lear expects of her - that is, by keeping her love secret - can Cordelia continue to be responsive to her own true feelings. ${ }^{27}$ Lear's subsequent fury and ruthlessness comes not from his doubts as to whether Cordelia really loves him, but rather from his having to accept their mutual love and dependence on one another, which requires that he reveals himself to Cordelia. By failing to expose his dependence, Lear rejects both the one he loves and her love for him. ${ }^{28}$ In other words, by wanting to possess Cordelia's love as one possesses a material object (owning it while not being owned by it) Lear ends up losing what he already had: a loving relationship.

This interpretation touches on a fundamental aspect of acknowledgment according to Cavell - namely, that acknowledging entails revealing oneself to the other, making oneself known, handing oneself over to the other to be either accepted or rejected. To acknowledge Cordelia's love Lear must reveal himself as desiring that love, as loving her back, as being weakened by love and thus vulnerable to his beloved. Cavell's ethical response to skepticism thus arises as one of revealing oneself to the other, of being determined by that other, which is the very opposite of self-determination.

Lear's failure to acknowledge leads to tragedy, for after banishing Cordelia from his kingdom, Lear must now reveal not only his feelings towards her, but he must also recognize that he has distorted their relationship. As Cavell puts it, Lear must reveal

27 Hammer, Stanley Cavell: Skepticism, Subjectivity and the Ordinary, p. 79.

28 Ibid. 
"that he is her unjust banishing father." 29 It is out of his failure to reveal himself as her unjust father that Cordelia dies, which Cavell takes to mean that "every falsehood, every refusal of acknowledgment, will be tracked down. In the realm of spirit... there is absolute justice." ${ }^{30}$ Lear knows that his frustration does not in fact come from uncertainty as to whether Cordelia loves him or not. Instead, he is incapable of coming to terms with his human condition - with the fact that he loves her, and is thus dependent on a finite and fragile being, so finite and so fragile as to die in his hands by the end of the play. But in the fashion of a good skeptic, Lear converts this human condition into a riddle, into an intellectual lack: "Can I know that she loves me?" And yet, as I have said in the previous sections, the inner states of the other human being are not up to proof; they exist beyond the scope of scientific evidence, of ocular testimony, of certificates and contracts. Behind the skeptic's demanding rationality, therefore, stands an unbearable fear of disappointment with the other's too-human finitude, which gets converted into an impossible intellectual demand. In our narcissism, we wish to be grand, which means hiding from the finite other, for to acknowledge him entails joining his kind. Shakespearean theatre thus shows us that theatricality must be defeated.

\section{LEVINAS, CAVELL AND THE PRIMACY OF THE ETHICAL}

I have so far exposed Cavell's views on the ethical danger of ordinary-language skepticism, that is, the danger of reducing the other person to a philosophical puzzle or an intellectual lack. This attitude becomes one of domination or possession, for the skeptic wishes to contain the other within the limits of his knowledge. Lear wants, as was said, a certificate of love from Cordelia, so that all of Cordelia's being is in there, and nothing is outside; Cordelia would then become completely known, thoroughly revealed, like an aircraft to a Boeing engineer. The skeptic's tragic fate comes from placing epistemology first and ethics second, that is, from wanting to know before acknowledging.

It is at this point that we find the unexpected similarity between Cavell and Levinas. Both philosophers converge on the Levinasian maxim that "ethics is first philosophy." Cavell criticizes ordinary-language philosophers for wanting criteria to cover the full depths of the other person's being. Levinas, in his turn, similarly attacks phenomenology - the philosophical tradition he has inherited from Husserl and Heidegger - for reducing the other to a term within language, to a phenomenon within the world of consciousness. In the following part of my essay, I will first introduce Levinas' critique of phenomenology, and then compare the two thinkers. Such a comparison is as tempting as it is unexplored. Despite having mentioned his surprise with Levinas late in his career, Cavell has not himself devoted the time to

29 Cavell, The Claim of Reason, p. 429.

30 Cavell, Must we Mean What We Say, p. 309. 
studying Levinas extensively. What follows is, I believe, much needed - and just as with anything done for the first time, it might require successive attempts.

\subsection{A SKETCH OF LEVINASIAN PHENOMENOLOGY}

Phenomenology is the descriptive study of what appears, of what is being (re-)presented to consciousness. However, to appear as phenomena, beings must be identified as this or that (I see this as a chair). In the absence of any identification, there would only be a rustling of a totally anonymous and shapeless "there is" (il y a) in which everything gets confused with everything else. The identity of a phenomenon as this or that is its thematization: "Being manifests itself by becoming a theme," ${ }^{31}$ that is, by being gathered, centered and posited as this or that. Levinas emphasizes the lack of a pure receptivity in the way that consciousness "takes" or posits something as something else. The commentator Adriaan Peperzak says that "there is a sort of sovereignty in this way of getting in touch with the given. Consciousness leads the game and determines the positions of the pawns." 32 The logos overcomes the pre-phenomenal chaos and establishes an order in the anonymous rustling of Being. Every phenomenon thus becomes a Said (un Dit); that is, the thematic presentation of a being, the gathering of an identification that consciousness imposes on the "there is" (il y a).

According to Levinas, the whole history of Western philosophy has been dominated by the idea that beings and Being show themselves when expressed in speech or writing, when put in the Said. Levinas, however, criticizes the entire tradition by pointing to a simple fact: a discourse is always said by someone to one or more others (or to oneself as listener or reader). ${ }^{33}$ The saying of a said (le Dire d'un Dit) stands as one of the most ordinary and basic events of everyday life, as well as the root of the whole enterprise of civilization, unfolding itself in communication and social institutions. Why has philosophy failed to ignore the Saying (le Dire), concentrating exclusively on the Said (le Dit)? Language is not only and not primarily enunciation or expression, but rather communication - in talking or writing I always address my words (and myself) to someone. I expect someone to hear me. In speaking or writing to him, I initiate a relation between myself and him. One way of hiding this relation (the Saying) in the history of Western philosophy has been by treating it as a phenomenon comparable to other phenomena. However, the other person to whom I speak is not there before me as a phenomenon that I can observe, study, and analyze, but as someone to whom I offer something that I have felt, heard, studied, written, or said. To be sure, I can look at the color of somebody's eyes or contemplate someone's beauty, which I can describe in a generic phenomenology, but my relation to the other does not have a phenomenological structure. By treating or observing another in the way that would be appropriate to a phenomenon, I prevent myself from having an encounter with this person. In order to face someone who looks back

31 Peperzak, Beyond: The Philosophy of Emmanuel Levinas, p. 56.

32 Ibid.

33 Ibid., p. 61. 
at me, I must separate myself from the identifying and thematizing attitude described earlier, for if I were to see the Other as an interesting phenomenon (as someone with green eyes or a sweet voice), I would reduce the Other's otherness to an element of my thematic universe: the Other consequently would become absent. As Peperzak phrases it, in contrast to the phenomena that I can observe, the Other whom I meet as Other is invisible. ${ }^{34}$ Or in the words of Levinas, the Other is not a phenomenon, but rather an enigma. ${ }^{35}$

The theoretical intention is thus essentially incapable of taking one of the most ordinary experiences of everyday life seriously: it cannot do justice to the fact that my words are addressed to someone. The problem with philosophy - and the temptation which Levinas constantly tries to evade - is that, as soon as I want to concentrate on this experience, I betray it by making it into a theme. By becoming a theme, an address loses its very moment of Saying, that by which its signification is communicative, and thus it loses its orientation towards an actual or possible hearer. The "to" has changed into an "in front of" or "before" of an object that is present before consciousness. Levinas wants to convey, through his innovative writing (as if through an epiphany), the vocative in our language, the irreducible relation to the addressee, which is present in every sentence and every message (saying "Here I am!", "Me voici!"). Levinas' writing also attempts to reveal the inherent transcendence of communication, the fact that to speak is not comparable to noetico-noematic correlations, ${ }^{36}$ but rather to my offering the whole of my identifying acts - that is, the whole of my world - to someone who is not a part or moment or event within that whole. You, as the Other, are not to be found in my world - for you come from afar - and my response to your facing me precedes, and is more fundamental than, the domain of phenomenal beings. All of my themes and identifications are meant first and foremost to be given to you for your acknowledgement or denial. In my contact or proximity to you there is the mark of "the one-for-the-other," as Levinas says. ${ }^{37} \mathrm{I}$ give you my words - and myself - saying "See me, here and now," and, in doing so, I am in the accusative case: for it is up to you to accept or deny my words, to accept or deny myself. ${ }^{38}$ I thus find myself in a position of a "passivity beyond passivity." My obligations and responsibilities to you do not stem from any decision or contract originating in my will, for before I could even think, thematize, and freely choose, I have become responsible to you. Every thematization and every thought of mine is given and addressed to you; on the hither side of every Said of mine lies a Saying filled with responsibility for you.

34 Peperzak, Beyond: The Philosophy of Emmanuel Levinas, p. 63.

35 Ibid.

36 In Husserl's terminology, the noetic content is the mental act (say, an act of liking, of judging, or of remembering), which is directed towards an intentionally held object, "noema” (say, a book, a landscape, or one's childhood home).

37 Peperzak, Beyond: The Philosophy of Emmanuel Levinas, p. 67.

38 The expressions "See me, here and now," "Here I am," "I am in the accusative case," and then later "a passivity beyond passivity" all comprise the Levinasian terminology present throughout Otherwise than Being. 


\subsection{SOME POINTS OF AGREEMENT}

The position of ultimate passivity that I find myself in my ethical relation points to Levinas' maxim that "I am a hostage to the Other." As we have seen, Lear's wish to have a certificate of love from Cordelia (a Said) in exchange for land stands as a desperate attempt to avoid the ethical reality of ordinary language, to reduce the Other to a theme or a term in a contract, to mask one's existence as hostage to the finite Other. By setting up rulebooks and contracts that take you and I as signatories, I avoid an ethical engagement. Such was Lear's wish, but such was also Saul Kripke and John Austin's attempt to ground language on a rulebook (be it a manual on birdwatching), on something more "robust" and "independent" than the too-human Other. Kripke speaks of an "eerie feeling" when he realizes that "nothing ensures" that the other person will make the same mathematical projections as he has done in the past, for "there is no reason" we act and agree in language (or in mathematical functions) as we do. ${ }^{39}$ It as if, Kripke says, "the entire idea of meaning vanishes into thin air." 40 Cavell correctly responds by saying that something has vanished, but that in other ways it seems that language is "solider than ever." ${ }^{11}$ Suppose someone invites me to tea and lays out the toy tea set that belongs to his child's doll, and then proceeds to pour. I might not be able to reason with him, but I have choices beyond breaking with him or going away: I might try to humor him, or show him my trustworthiness by sipping from the toy cup, or I might serve the tea to my doll. ${ }^{42}$ Any Said that we might agree upon (a theme in the rulebook) has vanished, but the "signifyingness" (to use Levinas' expression), the Saying, the "one-for-the-other," the communicative and vocative element of language remains. It is in this sense that, prior to and more fundamental than my certainty or knowledge that we employ the same terms in the same way, I have an ethical responsibility for you, as my Other. Such an idea unites Cavell and Levinas, turning both into outcasts in the drama of Western philosophy.

We can also find this sense of passivity, and of the purely vocative aspect of language, in Cavell's mention of Rousseau in the final pages of The Claim of Reason. Cavell takes as paradigmatic of the discovery and acknowledgment of the Other the following "mythic" or "pre-historical" moment in Rousseau's Essay on the Origin of Language:

Upon meeting others, a savage man will initially be frightened. Because of his fear he sees the other as bigger and stronger than himself. He calls them giants... That is how the figurative word is born before the literal word, when our gaze is held in passionate fascination. ${ }^{43}$

The first naming of the Other is characterized by Rousseau in the form of an exclamation: upon meeting the Other, the savage man has an experience on the basis

39 Cavell, Philosophy the Day After Tomorrow, p. 135.

40 Kripke, Wittgenstein on Rules and Private Language, p. 22.

41 Cavell, Philosophy the Day After Tomorrow, p. 136.

42 Ibid.

43 See Rousseau, Essay on the Origin of Language, in the section entitled "That the first language had to be figurative." 
of which "he calls something out, something is called forth from him." ${ }^{44}$ From the Other's sheer otherness comes the fright and fascination which Rousseau defines in his mythic or pre-historic account as our exclamation and fascination with the other human being. Levinas, in a most similar fashion, says that "the face is the fact that a being affects me not in the indicative, but in the imperative," ${ }^{45}$ that the Other is a thick moral presence to me, a giant, commanding me from a position of height. The one moment in which Cavell distances himself from Levinas - and this might be the biggest distinction between the two thinkers - is when he emphasizes that the Other is ultimately not stronger or "higher" than the self. Rousseau says that:

After many experiences, the savage recognizes that these so-called giants are neither bigger nor stronger than he. Their stature does not approach the idea he had initially attached to the word giant. So he invents another name common to them and to him, such as the name man, for example, and leaves giant to the fictitious object that had impressed him during his illusion. ${ }^{46}$

Cavell follows Rousseau's reasoning by claiming that after the first frightful meeting with the Other, the savage decides, on the basis of noticing the empirical analogies between himself and others, to displace the first name called forth from him ("giant") in favor of another ("man"). ${ }^{47}$ It is crucial for Cavell to recognize this no-more-thanhuman status of the other person, because the realization of the beloved's finitude lies at the center of his interpretation of King Lear. If the Other is weak and finite, I am just as weak and finite for being dependent, through love, on that Other. For Levinas, however, the Other always remains a giant, so to speak, for "the face, still a thing among things, breaks through the form that nevertheless delimits it." ${ }^{8}$ The face is a physical entity, a thing among others, and yet it expresses the infinite, breaking through its finite form. The Other presents me with an ungraspable infinity, for I cannot encompass him in my thoughts and theories, in my themes and categories. The Other forever stays "infinitely transcendent, infinitely foreign." ${ }^{49}$

If the Other is my equal - and Lear's drama for Cavell is the admission that he is just as equal, just as finite as the Other - then my task is to accept my human condition and not hide in theatricality or deny acknowledgement. But if the Other is my superior - and the philosopher's drama for Levinas is the admission that the Other is not a theme in the phenomenal world - then my task is to renounce my autonomy and recognize my passivity towards the Other. In both cases, there is a lowering: Lear thinks of himself too highly and must now accept the lower condition of being just as human as Cordelia; the philosopher wants to place the Other among his themes and

\footnotetext{
44 Cavell, The Claim of Reason, p. 466.

45 Levinas, Collected Philosophical Papers, p. 21.

46 See Rousseau, Essay on the Origin of Language, in the section entitled "That the first language had to be figurative."

47 Cavell, The Claim of Reason, p. 466.

48 Levinas, Totality and Infinity, p. 197.

49 Ibid.
} 
ideas, all of which are his creations, but the Other stands outside as the receiving end and final destination of the philosopher's thematization. The distinction between 1), the Other being my finite equal and 2), the Other being entirely outside my world, being "what I myself am not," ${ }^{50}$ however, renders an important difference between Cavell and Levinas. Since the Cavellian Other is as finite as I am, I might burden him by "placing infinite demands on finite sources," ${ }^{1}$ and the Other might similarly place monstrous burdens on me, in which case I can say "No," I can choose not to engage (for in this scenario, either myself or the Other has not acknowledged our common human finitude). For Levinas, however, since the Other is an infinity beyond grasp not a part of my world of themes and ideas - my obligations and responsibilities to him stem from a most passive position, before any thought and thematization, and thus before any decision of my will. I have no choice but to say "Yes" to the Other if he approaches me with his nude face, without theatricality. ${ }^{52}$

Although in no way do I expect to exhaust all possible comparisons between these highly complex thinkers, in general, we might state that each of them reacts to the dominance of scientific positivism, of the social sciences, of categorization, that is, of taking the human as a term in a language, instead of recognizing that individuals address and are addressed by one another. In admitting this fact of (ordinary) language, both thinkers equally envision the supremacy of ethics, and its indispensable primacy over all other intellectual pursuits. Skepticism tries to sublimate language by reducing its very communicative element, its "signifyingness" to a term within the language. Ethics would then be governed according to social contracts, legal books, societal norms, moral codes - anything that can be fixed and established. But as I have shown, that is both impossible and tragic. Levinas and Cavell both try to return us to the ethical, to its inescapable presence in ordinary life. If the title of "first philosophy" once belonged to metaphysics (with Aristotle), then being transferred to epistemology (with Descartes), we can now safely say that, for Levinas and Cavell, ethics is prima philosophia.

As a concluding thought, I will end this investigation on Levinas and Cavell - the first of many others - with an aesthetic comparison. Kant's notion of the mathematical sublime might serve to describe the encounter with the Levinasian Other, which is an encounter with an infinite otherness that I cannot grasp (greifen). ${ }^{53}$ This mathematical

50 Levinas, Time and the Other, p. 83.

51 Cavell, The Claim of Reason, p. 470.

$52 \mathrm{I}$ include the conditional as a way to respond to the problem of hostages, which permeates Levinasian scholarship. The British philosopher Simon Critchley, for instance, has touched on this issue. As he explains, the Holocaust survivors who had invited him to speak in their London synagogue could not accept Levinas' command of being responsible for their persecutor. Their reaction, which strongly invokes the remembrance of National Socialism, made Critchley think that Levinas had gone too far, or become too "masochistic." One way to avoid this problem is to say that the Nazi guard does not present his face, in its destitution, nudity and vulnerability, but rather hides himself in the theatricality of cruelty. If there is a genuine human interaction, the ethical forcefulness of the Other's face commands me to say "Yes."

53 I have previously discussed this comparison between Levinas' ethics and Kant's aesthetics in an essay entitled "The Epiphany of the Face: Levinas and the Ethical-Religious Attitude," which I presented at the 5th Annual Graduate and Undergraduate Student Conference in Philosophy, at San Diego State University, on October 
sublime arises when we are confronted with something so large that it overwhelms our sensory capacity, when we cannot apprehend the magnitude of a given object. Looking at the starry night sky, for instance, with its multitude of galaxies and constellations, our senses reach up to a certain point, but reason can go further and conceive the idea of infinity, which exceeds any possible faculty of the imagination. Analogously, the face of the Other communicates an otherness which cannot possibly be grasped by sameness: "It cannot be comprehended, that is, encompassed. The Other remains infinitely transcendent, infinitely foreign." ${ }^{54}$ Just as what lies beyond the stars, the Other cannot receive a place in my phenomenal world, cannot be categorized in my sameness or apprehended and understood by my intelligence. A vision of the Other is at most an epiphany, or ekstasis ("stepping outside"). For Kant, the mathematical sublime contrasts, in its turn, with the dynamic sublime, and just as the first belongs to Levinas, so would the second correspond to Cavell. In Kant's words, the dynamic sublime is when nature creates a fearfulness "without us being afraid of it." 55 Looking at immensely powerful waves hitting the rocks in the coast, we know they can annihilate us, wipe us out with one hit, and yet their awesome power does not give us a sense of threat from afar. Analogously to Cavell, you might not follow the same rules as I do, we might not mean the same by what we say, but rather than assuming the skeptical position of demanding conformity, I turn my spade expressing patience. My rulebooks might vanish into thin air, my Kripkean wishes can be destroyed with a single hit, and yet I accommodate myself to the Other; communication might threaten to break down in a second, but that opens for us the ethical realm of language without rules.

\section{BIBLIOGRAPHY}

Austin, John L., James Urmson and Geoffrey Warnock. “Other Minds” Philosophical Papers. Oxford: Clarendon Press, 1961.

Berkeley, George. Three Dialogues between Hylas and Philonous. New York: Liberal Arts, 1954.

Cavell, Stanley. Must We Mean What We Say: A Book of Essays. Cambridge: Cambridge University Press, 1976.

Philosophy the Day after Tomorrow. Cambridge, MA: Belknap of Harvard University Press, 2005.

14th, 2015. For more information regarding Kant's mathematical sublime, see Ginsborg, "Kant's Aesthetics and

Teleology" in the Stanford Encyclopedia of Philosophy. For the full website, see Ginsborg in the bibliography.

54 Levinas, Totality and Infinity, p. 194.

55 Kant, Critique of Judgment, $\$ 28$ 
The Claim of Reason: Wittgenstein, Skepticism, Morality, and Tragedy. Oxford: Clarendon, 1979.

Descartes, René. Meditationes De Prima Philosophia. Translated by Artur Buchenau, Lipsiae: Meiner, 1913.

Ginsborg, Hannah. "Kant's Aesthetics and Teleology." Stanford University. Stanford University, 02 July 2005. http://plato.stanford.edu/entries/kant-aesthetics/.

Hammer, Espen. Stanley Cavell: Skepticism, Subjectivity, and the Ordinary. Cambridge: Polity, 2002.

Hume, David. An Enquiry concerning Human Understanding: A Letter from a Gentleman to His Friend in Edinburgh. Indianapolis: Hackett Pub., 1977.

Kant, Immanuel. Critique of Judgment. Translated by J. H. Bernard New York: Hafner Pub., 1951.

Critique of Pure Reason. Translated by Paul Guyer and Allenn W. Wood. Cambridge: Cambridge University Press, 1999.

Kripke, Saul A. Wittgenstein on Rules and Private Language: An Elementary Exposition. Cambridge, MA: Harvard University Press, 1982.

Levinas, Emmanuel. Humanism of the Other. Translated by Nidra Poller. Urbana, IL: University of Illinois, 2006.

Ethics and Infinity. Translated by Philippe Nemo. Pittsburgh: Duquesne University Press, 1985.

Time and the Other: And Additional Essays. Translated by Richard A. Cohen. Pittsburgh: Duquesne University Press, 1987.

Collected Philosophical Papers. Translated by Dordrecht, The Netherlands: Nijhoff, 1987.

- Difficult Freedom: Essays on Judaism. Baltimore: Johns Hopkins University Press, 1990.

- Otherwise than Being, Or, Beyond Essence. Pittsburgh, PA: Duquesne University Press, 1998.

Totality and Infinity: An Essay on Exteriority. Pittsburgh, PA: Duquesne University Press, 1969.

Peperzak, Adriaan Theodoor. Beyond: The Philosophy of Emmanuel Levinas. Evanston, IL: Northwestern University Press, 1999.

Pessoa, Fernando. Poesias Inéditas (1930-1935). Lisboa: Ediçôes Atica. Plato, and Nicholas Denyer. Protagoras. Cambridge: Cambridge University Press, 2008. 
Rousseau, Jean-Jacques. Essay on the Origin of Languages. Translated by Johann Gottfried. Chicago: University of Chicago, 1966.

Wittgenstein, Ludwig, Philosophical Investigations: The German Text, with a Revised English Translation. Translated by G.E.M. Anscombe. Oxford: Blackwell, 2001. 